\title{
Evaluasi Struktur Bangunan Cagar Budaya di Jl. Rajawali No. 3- 5, Surabaya
}

\author{
Akhmad Yusuf Zuhdy, R. Buyung Anugraha A., Sungkono \\ Program Studi Diploma Teknik Sipil FTSP ITS, Surabaya \\ Email: yusuf_zuhdi@ce.its.ac.id
}

\begin{abstract}
This study intends to evaluate structure of heritage building at Rajawali Rd. No. 3-5, Surabaya. The evaluation is based on SNI 03-1726-2002 code which describes required allowable load service and ultimate load service of building structural component. A structural analysis has been performed to evaluate the structural component such us foundation, beam, column of the building. Result shows that the building is remain suitable for office building, but it required an improvement to strengthen the column component.
\end{abstract}

Keywords: structural evaluation, heritage building, allowable load service, ultimate load service.

\section{Abstrak}

Studi ini bertujuan mengevaluasi kelayakan struktur bangunan cagar budaya yang beralamatkan di Jl. Rajawali No. 3-5, Surabaya, untuk mengetahui apakah masih memenuhi syarat secara teknis. Parameter teknis yang digunakan mengacu pada SNI 03-1726-2002 yang menjelaskan tentang persyaratan batas kerja layan dan ultimate suatu komponen struktur bangunan. Analisa struktur dilakukan pada komponen pondasi, dinding, balok, kolom gedung tersebut. Hasil analisa menunjukkan bahwa secara umum struktur bangunan masih layak untuk difungsikan sebagai gedung perkantoran, namun memerlukan perbaikan dan perkuatan pada pelat lantai, balok anak, balok induk, dan kolom.

Kata kunci: evaluasi struktur, batas kerja layan, batas kerja ultimite, cagar budaya.

\section{Pendahuluan}

Bangunan Gedung di jl. Rajawali 3-5, Surabaya, akan dioptimalkan penggunaannya dan difungsikan sebagai gedung CBC Surabaya Jembatan Merah. Gedung tersebut merupakan salah satu gedung cagar budaya Kota Surabaya dan tidak ada catatan yang resmi sejak kapan mulai difungsikan sepenuhnya sebagai salah satu perusahaan perbankan nasional yang berada di kota Surabaya. Gedung tersebut terdiri dari 2 (dua) lantai yang saat ini berfungsi sebagai tempat penyimpanan arsiparsip perbankan, kesekretariatan pensiunan karyawan Bank dan untuk pelatihan/training karyawan. Untuk pengalihfungsian gedung tersebut, maka dilakukan uji material struktur gedung. Dari hasil pelaksanaan uji material elemen struktur tersebut, diperoleh beberapa parameter yang dijadikan dasar untuk memprediksikan kualitas material struktur gedung pada saat ini. Pelaksanaan evaluasi dilakukan guna mengetahui kekuatan sisa serta perbaikan-perbaikan yang harus dilakukan sehubungan dengan alih fungsi daripada gedung. Datadata teknis yang digunakan antara lain data goemetri bangunan, dimensi elemen-elemen struktur (meliputi dimensi plat lantai, balok dan kolom), kuat tekan beton, kuat tarik baja serta posisi penulangan yang terpasang.

\subsection{Lokasi Studi}

Untuk pelaksanaan studi ini, berlokasi di jalan Rajawali no. 3 - 5 Surabaya 
berada di kawasan perdagangan wilayah Surabaya Utara. Untuk batas-batas dari gedung seperti pada gambar 1 adalah sebagai berikut:

Sebelah Utara : Pusat Grosir Jembatan Merah Plasa

Sebelah Selatan : Kawasan Perumahan Sebelah Barat : Hotel Ibis Surabaya

Sebelah Timur : Kantor Cabang Bank Mandiri Rajawali

\subsection{Data Geometri}

Gedung ini terdiri dari 2 (dua) lantai dengan luasan mencapai 1250,25 $\mathrm{m}^{2}$. Struktur balok yang dimaksud pada bagian ini adalah struktur balok sebagai pendukung pelat beton lantai 2. Data yang digunakan dalam perhitungan berdasarkan data dari uji material yang telah dilaksanakan oleh PT. ITS Kemitraan sebelumnya. Pada gedung ini, baik pada struktur balok induk maupun balok anak, kedua-duanya merupakan balok komposit baja dan beton. Untuk balok induk mempunyai dimensi 250 x 500 mm dengan jarak antar balok $4000 \mathrm{~mm}$, sedangkan pada balok anak mempunyai dimensi 200 x $300 \mathrm{~mm}$ dengan jarak antar balok $750 \mathrm{~mm}$. Struktur kolom gedung terdiri dari 2 macam dimensi kolom. Kolom pertama merupakan kolom komposit baja dan beton berbentuk lingkaran dengan diameter $400 \mathrm{~mm}$, sedangkan kolom kedua merupakan kolom batu bata berbentuk persegi empat dengan dimensi 800 x $600 \mathrm{~mm}$.

Elemen struktur yang ada pada gedung ini merupakan elemen komposit baja dan beton yang terdiri dari balok persegi empat dengan dimensi $200 \times 300$ mm dan 250 x $500 \mathrm{~mm}$ serta kolom lingkaran dengan diameter $400 \mathrm{~mm}$. Detail balok dan kolom sebagai elemen struktur pada gedung tersebut dapat dilihat pada gambar 2 .

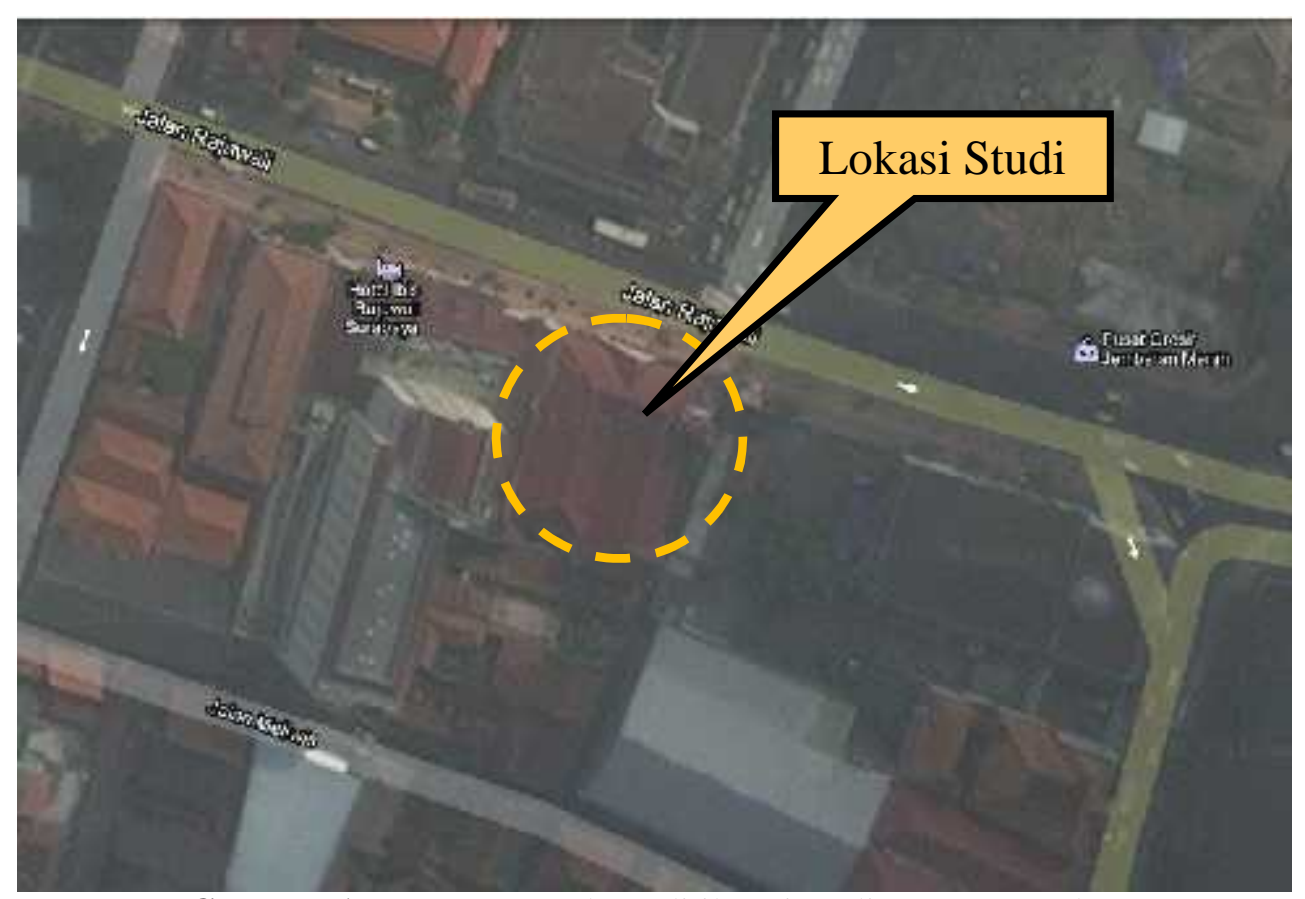

Gambar 1. Bangunan gedung di jl. Rajawali no. 3-5 Surabaya 


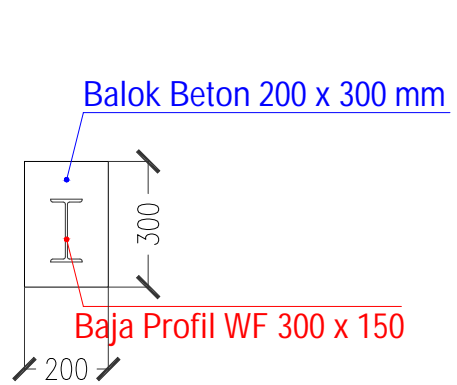

Balok $200 \times 300$
Balok Beton $250 \times 500 \mathrm{~mm}$

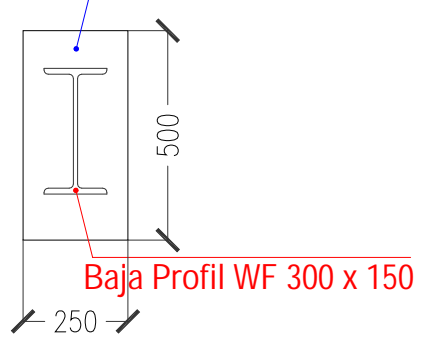

Balok $250 \times 500$
Kolom Beton $\varnothing 400 \mathrm{~mm}$

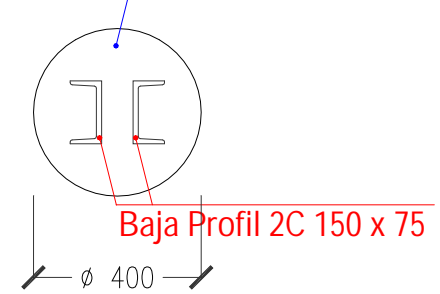

Kolom Ø 400

Gambar 2. Detail Elemen Struktur Gedung

\section{Metodologi}

\subsection{Kinerja Batas Layan}

Berdasarkan SNI 03-1726-2002 kinerja batas layan struktur gedung ditentukan oleh simpangan antar-tingkat akibat pengaruh Gempa Rencana, untuk membatasi terjadinya pelelehan baja dan peretakan beton yang berlebihan, disamping untuk mencegah kerusakan non struktur dan ketidaknyamanan penghuni. Untuk memenuhi persyaratan kinerja batas layan struktur gedung, dalam segala hal simpangan antartingkat yang dihitung dari simpangan struktur gedung tidak boleh melampaui 0,03/R kali tinggi tingkat yang bersangkutan atau $30 \mathrm{~mm}$, bergantung yang mana yang nilainya kecil.

\subsection{Kinerja Batas Ultimate}

Kinerja batas ultimit struktur gedung ditentukan oleh simpangan dan simpangan antar tingkat maksimum struktur gedung akibat pengaruh Gempa Rencana dalam kondisi struktur gedung di ambang keruntuhan. Hal ini untuk membatasi kemungkinan terjadinya keruntuhan struktur gedung yang dapat menimbulkan korban jiwa manusia dan untuk mencegah benturan berbahaya antar-gedung atau antar bagian struktur gedung yang dipisah dengan sela pemisah (sela dilatasi). Untuk memenuhi persyaratan kinerja batas ultimit struktur gedung, dalam segala hal simpangan antar-tingkat yang dihitung dari simpangan struktur gedung, tidak boleh melampaui 0,02 kali tinggi tingkat yang bersangkutan.

\subsection{Pengumpulan Data}

Data-data yang diperlukan adalah data dimensi komponen struktur serta kualitas bahan yang meliputi antara lain:

1. Kuat tekan beton

Sebelum data dimasukkan dalam melakukan analisis struktur, maka perlu diketahui kualitas beton, terutama kuat tekannya. Untuk mengetahui kuat tekan beton dapat dilakukan uji nondistructive test (uji tidak merusak) dengan pengambilan sampel bor inti (core case), Schmidt Hammer Test, UPV (Ultrasonic Pulse Velocity) dan lain lain. Pengujian bahan dilakukan pada bagian struktur yang pada dugaan awal diragukan kekuatannya. 


\section{Baja Tulangan}

Tegangan leleh baja tulangan ditentukan berdasar data mutu baja yang digunakan pada pelaksanaan pembangunan (as build drawing).

\subsection{Penilaian Kekuatan Penampang Komponen Struktur}

Apabila dimensi komponen struktur dan kualitas bahan sudah diketahui, maka kekuatan struktur dalam mendukung momen, gaya geser, dan aksial dapat dianalisis. Komponen struktur harus mempunyai kekuatan tersedia $\mathrm{R}$ (resistance) minimum sama dengan kekuatan diperlukan atau kuat perlu U (ultimate) atau dapat dituliskan $\mathrm{R} \geq \mathrm{U}$. Kuat tersedia $\mathrm{R}$ adalah sama dengan kapasitasnya (kuat nominal) dikalikan dengan faktor reduksi kekuatan $\varphi$ sesuai pasal 22.2.5 SNI-2847-2002. Kuat perlu U dihitung berdasarkan kombinasi beban, masing-masing dikalikan dengan faktor beban $\gamma$ sesuai pasal 11.1. SNI-28472002.

\section{Hasil dan Pembahasan}

\subsection{Hasil Uji Material Struktur}

\subsubsection{Hasil uji kuat tekan material beton}

Material beton hasil core drill diperoleh hasil uji kuat tekan beton maksimum $\mathrm{f}_{\mathrm{c}}{ }^{\prime}=153,10 \mathrm{~kg} / \mathrm{cm}^{2}$ dan minimal $\mathrm{f}_{\mathrm{c}}{ }^{\prime}=$ $66,51 \mathrm{~kg} / \mathrm{cm}^{2}$ serta rata-rata sebesar $\mathrm{f}_{\mathrm{c}}{ }^{\prime}=$ $121,71 \mathrm{~kg} / \mathrm{cm}^{2}$. Sedangkan untuk elemen dinding/tembok diperoleh nilai minimal $\mathrm{f}_{\mathrm{c}}{ }^{\prime}=26,60 \mathrm{~kg} / \mathrm{cm}^{2}$ dan maksimum $\mathrm{f}_{\mathrm{c}}{ }^{\prime}=39,90 \mathrm{~kg} / \mathrm{cm}^{2}$ dan rata rata $f_{c}{ }^{\prime}=31 \mathrm{~kg} / \mathrm{cm}^{2}$.

\subsubsection{Hasil uji ultrasonic}

Pengujian dilakukan pada elemen struktur kolom, balok dan plat. Dari pembacaan alat ultrasonic diambil harga kecepatan rambat rata-rata (v), harga inilah yang akan menunjukkan nilai kepadatan beton. Dari hasil test tersebut akan didapatkan kecepatan rambat gelombang ultrasonic dari setiap elemen yang diuji diperoleh nilai ratarata sebesar $1881,00 \mathrm{~m} / \mathrm{s}$. Dari hasil rata-rata pengujian ultrasonic tersebut bila dibandingkan dengan klafisikasi hasil UPV menurut British Standart (BSI) 1881-1986 (2004) seperti terlihat pada tabel 1 menunjukkan bahwa kepadatan beton pada gedung tersebut dikategorikan sebagai beton dengan Kepadatan Kurang.

Tabel 1. Klasifikasi Beton menurut BSI 1881-1986 (2004)

\begin{tabular}{cc}
\hline Kecepatan V $(\mathrm{m} / \mathrm{s})$ & Klasifikasi \\
\hline $\mathrm{V}<2130$ & Kurang \\
\hline $2130<\mathrm{V}<3060$ & Cukup \\
\hline $3060<\mathrm{V}<3670$ & Cukup Baik \\
\hline $3670<\mathrm{V}<4570$ & Baik \\
\hline $\mathrm{V}>4570$ & Baik Sekali \\
\hline
\end{tabular}

\subsubsection{Hasil uji hammer}

Hasil pengujian hammer untuk berbagai lokasi di struktur gedung tersebut terlihat pada Tabel 2. Evaluasi selanjutnya terhadap beton dengan hammer test dilakukan untuk melihat kondisi keseragaman mutu beton bangunan tersebut. Hasil evaluasi tes hammer yang disajikan pada Tabel 2 dibandingkan dengan klasifikasi keseragaman yang diambil dari ACI214R-02 (Evaluation of 
Tabel 2. Hasil Uji Hammer Test

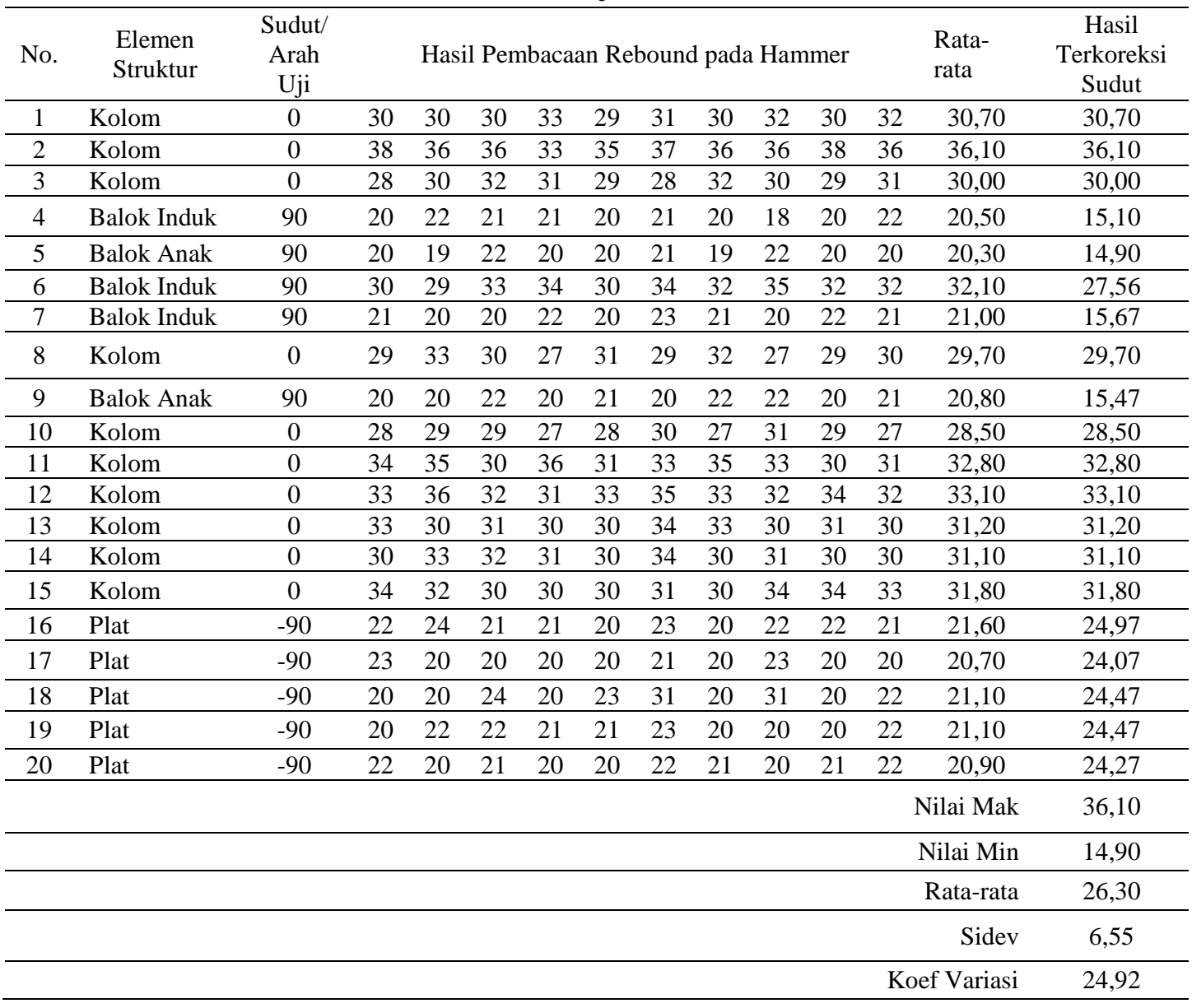

Strength Test Results) seperti terlihat tabel 3 menunjukkan bila beton mempunyai koefisien variasi lebih dari $6 \%$, maka beton diindikasikan mempunyai tingkat keseragaman yang kurang baik seperti pada tabel 3 .

\subsubsection{Hasil uji barlocator}

Pengujian ini dilakukan untuk mengetahui posisi tulangan yang terpasang pada elemen struktur gedung baik kolom, balok maupun plat. Dari hasil barlocator diperoleh tebal selimut ratarata sebesar $35,34 \mathrm{~mm}$.

\subsubsection{Penyelidikan tanah di labo- ratorium}

Hasil penyelidikan tanah baik di lapangan maupun di laboratorium diperoleh perkiraan daya dukung tanah setempat, baik untuk penggunaan pondasi dangkal ataupun pondasi dalam (bor pile atau tiang pancang). Untuk analisa pondasi dangkal diperoleh daya dukung sebagaimana tabel 4 .

\subsection{Analisa Pembebanan}

Simulasi pembebanan yang diberikan pada struktur bangunan gedung, terdiri dari berat sendiri struktur (balok, kolom, pelat beton, dinding bata), berat peralatan mekanikal \& elektrikal, serta beban hidup gedung. 
Tabel 3. Klasifikasi Keseragaman Tes Untuk Beton

\begin{tabular}{|c|c|c|c|}
\hline \multirow{2}{*}{\multicolumn{2}{|c|}{ Class of operation }} & \multicolumn{2}{|c|}{ Coefficient of } \\
\hline & & Excellent & Very \\
\hline \multicolumn{2}{|c|}{ Field control testing } & Below 3,0 & $3,0 t$ \\
\hline \multicolumn{2}{|c|}{$\begin{array}{c}\text { Laboratory trial } \\
\text { batches }\end{array}$} & Below 3,0 & \\
\hline \multicolumn{4}{|c|}{ Sumber: BS 1881-1896 } \\
\hline \multicolumn{4}{|c|}{$\begin{array}{l}\text { Tabel 4. Daya dukung pondasi dangkal } \\
\text { berdasarkan persamaan Terzaghi (local } \\
\text { shear failure) }\end{array}$} \\
\hline \multicolumn{4}{|c|}{ Bor I.0 } \\
\hline $\begin{array}{l}\text { Kedalaman (Df) } \\
\text { meter }\end{array}$ & $\begin{array}{l}\text { Angka } \\
\text { Keamanan }\end{array}$ & \multicolumn{2}{|c|}{$\begin{array}{c}\text { Tegangan Tanah } \\
\text { yang diijinjan }\left(\sigma_{\mathrm{t}}\right) \\
\left(\mathrm{kg} / \mathrm{cm}^{2}\right)\end{array}$} \\
\hline \multirow{2}{*}{-1.50} & 2 & \multirow{2}{*}{\multicolumn{2}{|c|}{$\begin{array}{l}0,37 \\
0,25\end{array}$}} \\
\hline & 3 & & \\
\hline \multirow{2}{*}{-3.00} & 2 & \multicolumn{2}{|c|}{0,58} \\
\hline & 3 & \multicolumn{2}{|c|}{0,39} \\
\hline \multirow{2}{*}{-5.00} & 2 & \multicolumn{2}{|c|}{0,76} \\
\hline & 3 & \multicolumn{2}{|c|}{0,51} \\
\hline \multicolumn{4}{|l|}{ Bor II.0 } \\
\hline \multirow{2}{*}{-1.50} & 2 & \multicolumn{2}{|c|}{0,43} \\
\hline & 3 & 0,29 & \\
\hline \multirow{2}{*}{-3.00} & 2 & \multicolumn{2}{|l|}{0,68} \\
\hline & 3 & \multicolumn{2}{|l|}{0,46} \\
\hline \multirow{2}{*}{-5.00} & 2 & \multicolumn{2}{|c|}{0,92} \\
\hline & 3 & \multicolumn{2}{|l|}{0,62} \\
\hline \multicolumn{4}{|l|}{ Bor III.0 } \\
\hline \multirow{2}{*}{-1.50} & 2 & \multirow{2}{*}{\multicolumn{2}{|c|}{0,40}} \\
\hline & 3 & & \\
\hline \multirow{2}{*}{-3.00} & 2 & \multicolumn{2}{|l|}{0,62} \\
\hline & 3 & \multicolumn{2}{|l|}{0,41} \\
\hline \multirow{2}{*}{-5.00} & 2 & \multirow{2}{*}{\multicolumn{2}{|c|}{$\begin{array}{l}0,98 \\
0,65\end{array}$}} \\
\hline & 3 & & \\
\hline
\end{tabular}

Besarnya beban yang digunakan dalam perencanaan struktur adalah sebagai berikut:

a. Beban Gravitasi

1. Beban Mati.

Pembebanan Lantai 2
a. Berat sendiri pelat lantai $\quad: 288 \mathrm{~kg} / \mathrm{m}^{2}$
b. Berat penutup Lantai $\quad: 46 \mathrm{~kg} / \mathrm{m}^{2}$
c. Berat spesi
$(3 \mathrm{~cm})$
$: 60 \mathrm{~kg} / \mathrm{m}^{2}$
d. Berat instalasi

$\begin{array}{ll}\mathrm{M} / \mathrm{E} & : \underline{40 \mathrm{~kg} / \mathrm{m}^{2}}+ \\ \mathrm{qd}_{1} & =434 \mathrm{~kg} / \mathrm{m}^{2}\end{array}$

e. Beban mati dinding $\left(\mathrm{qd}_{2}\right)$ : $552 \mathrm{~kg} / \mathrm{m}^{1}$

Pembebanan Atap

a. Berat sendiri

$$
\text { Atap : } 150 \mathrm{~kg} / \mathrm{m}^{2}
$$

b. Berat penggantung

$$
\text { Plafon } \quad: 5 \mathrm{~kg} / \mathrm{m}^{2}
$$

c. Berat plafon : $10 \mathrm{~kg} / \mathrm{m}^{2}$

d. Berat instalasi

$$
\begin{array}{ll}
\mathrm{M} / \mathrm{E} & : \underline{40 \mathrm{~kg} / \mathrm{m}^{2}}+ \\
\mathrm{ql}_{1} & =205 \mathrm{~kg} / \mathrm{m}^{2}
\end{array}
$$

2. Beban Hidup

Beban hidup untuk Gedung ditentukan berdasarkan Peraturan Pembebanan Indonesia untuk Gedung 1983, yaitu:

- Lantai untuk gedung perkantoran : $250 \mathrm{~kg} / \mathrm{m}^{2}$

- Lantai untuk ruang pertemuan : $400 \mathrm{~kg} / \mathrm{m}^{2}$

- Konstruksi atap: $50 \mathrm{~kg} / \mathrm{m}^{2}$

Koefisien reduksi pembebanan terhadap distribusi beban hidup,

- Untuk perencanaan balok induk dan portal $\quad: 0,75$

- Untuk peninjauan gempa: 0,30

b. Beban Gempa Statik Ekivalen Peninjauan beban gempa ditinjau secara analisa dinamis 3 dimensi dengan metode statik ekivalen. Ekivalensi beban gempa terhadap struktur gedung, CBC Surabaya 
Jembatan Merah dihitung sebagai berikut;

1. Pembebanan Lantai 2 (luas lantai $775.16 \mathrm{~m}^{2}$ )

Beban Mati

a. Pelat lantai: $223246.08 \quad \mathrm{~kg}$

b. Balok induk $250 \times 500 \mathrm{~mm}$ $: 103521 \quad \mathrm{~kg}$

c. Balok anak 200 x $300 \mathrm{~mm}$ $: 175104 \quad \mathrm{~kg}$

d. Kolom $\varnothing 500 \mathrm{~mm}$

$$
\text { : } 73728 \quad \mathrm{~kg}
$$

e. Kolom 800 x $600 \mathrm{~mm}$ : $73728 \quad \mathrm{~kg}$

f. Dinding batu bata : $1800 \quad \mathrm{~kg}$

g. Instalasi $\mathrm{M} / \mathrm{E}$

$$
\text { WD } \quad \frac{: 31006.40 \mathrm{~kg}+}{=632,057.48 \mathrm{~kg}}
$$

Beban Hidup

a. Beban hidup : $310.064 \mathrm{~kg}$

b. Koefisien reduksi : 0.30

$\mathrm{WL}=93019.2 \quad \mathrm{~kg}$

2. Pembebanan Atap

Beban Mati

a. Berat sendiri atap

$$
: 116274.00 \quad \mathrm{~kg}
$$

b. Berat penggantung plafon

$$
\text { : } 3875.80 \quad \mathrm{~kg}
$$

c. Berat plafon

$$
\text { : } 7751.60 \quad \mathrm{~kg}
$$

d. Berat instalasi $\mathrm{M} / \mathrm{E}$

$$
\text { WD } \quad \begin{aligned}
& : 19379.00 \mathrm{~kg}+ \\
& =147280.40 \mathrm{~kg}
\end{aligned}
$$

Beban Hidup/Air Hujan

$$
\text { (WL) = }=15503.20 \quad \mathrm{~kg}
$$

W total lantai $2 \&$ atap

$$
=926308.88 \mathrm{~kg}
$$

Waktu Getar Empiris (T)

$\mathrm{hn}=8 \mathrm{~m}$

$\mathrm{Ct}=0,07$
$\mathrm{T}=\mathrm{Ct} .(\mathrm{hn})^{3 / 4}$

$\mathrm{T}=0,35$ detik

Kontrol pembatasan $\mathrm{T}$

$\xi=0,17$

$\mathrm{n}=3$

$\mathrm{T}=0,51$ detik $>0,348(\mathrm{Ok})$

Koefisien Gempa Dasar (C)

Daerah zone gempa, Wilayah Gempa 2, lihat gambar 2 .

Kondisi tanah lunak

Faktor respon spektrum $\quad \mathrm{C}=0.5$

Faktor Keutamaan Struktur I

$\mathrm{I}=1.6 \quad$ (Bangunan Monumental)

Faktor Tahanan Lebih

$\mathrm{R}=3,5 \quad$ (daktilitas terbatas)

Gaya Geser Horisontal

$$
\begin{aligned}
\mathrm{V} & =\left(\mathrm{C}_{1} . \mathrm{I} / \mathrm{R}\right) \mathrm{W}_{\mathrm{t}} \\
& =205597.18 \quad \mathrm{~kg}
\end{aligned}
$$

Selanjutnya untuk distribusi gaya geser horisontal pada tiap lantai nya bisa ditunjukkan pada tabel 5 .

c. Kombinasi Pembebanan

Komponen pembebanan yang digunakan untuk analisa struktur konstruksi gedung terdiri dari beban mati, beban hidup, dan beban gempa statik ekivalen. Beban-beban tersebut dikombinasikan dengan menambahkan factor load sebagai berikut:

1. $1,4 \mathrm{DL}$

2. $1,2 \mathrm{DL}+1,6 \mathrm{LL}$

3. $1,2 \mathrm{DL}+1,0 \mathrm{LL}+(1,0 \mathrm{Ex}-0,3 \mathrm{Ey})$

4. $1,2 \mathrm{DL}+1,0 \mathrm{LL}+(0,3 \mathrm{Ex}-1,0 \mathrm{Ey})$

5. $0,9 \mathrm{DL}+(1,0 \mathrm{Ex}-0,3 \mathrm{Ey})$

6. $0,9 \mathrm{DL}+(0,3 \mathrm{Ex}-1,0 \mathrm{Ey})$

7. $\mathrm{DL}+\mathrm{LL}$

dimana:

$\mathrm{DL}=$ Beban Mati

LL = Beban Hidup

$\mathrm{E}=$ Beban Gempa 


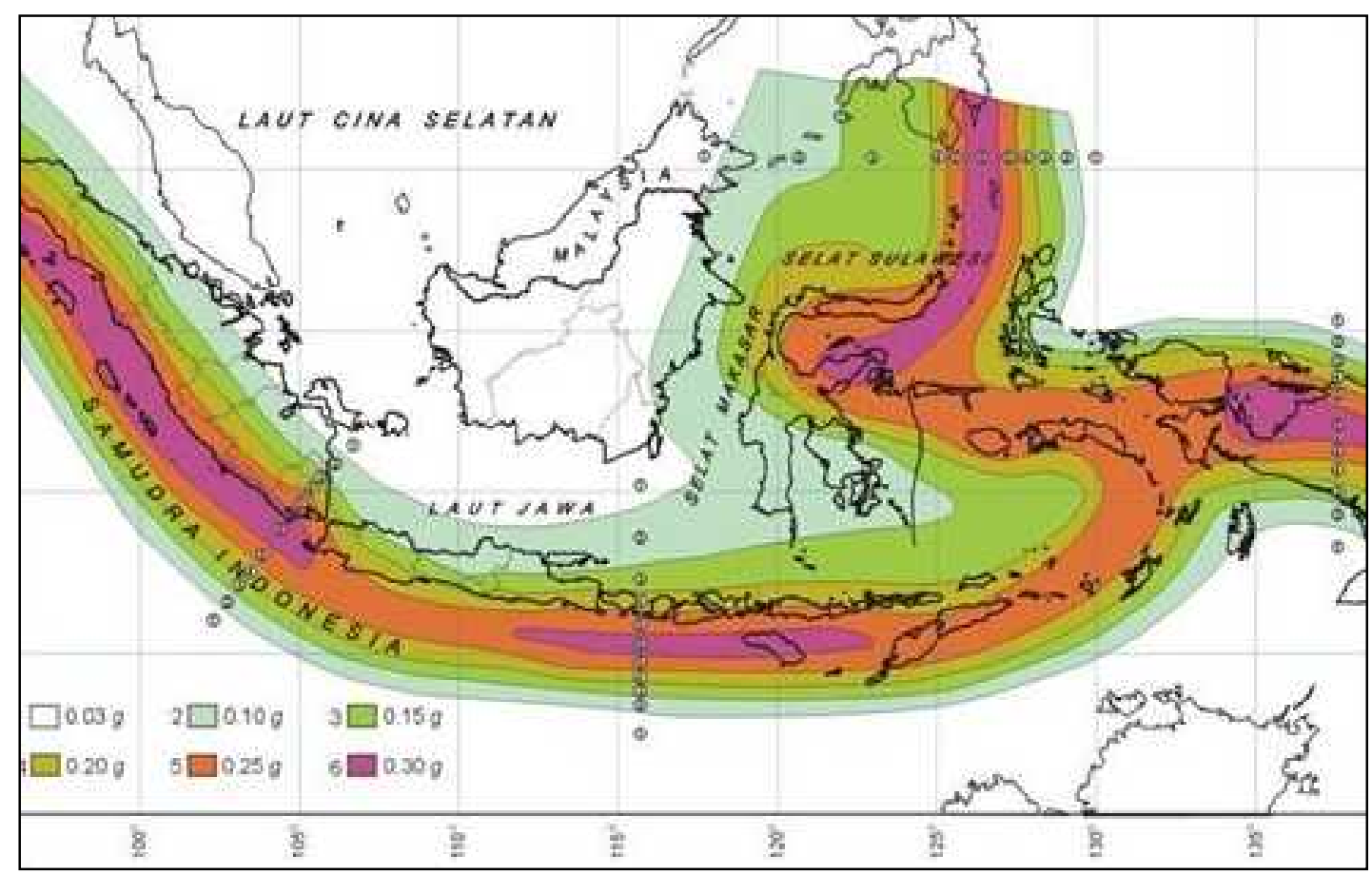

Gambar 3. Peta Wilayah Zona Gempa Indonesia sesuai SNI 03-1726-2002

Tabel 5. Distribusi Geser Horisontal Pada Tiap Lantai

\begin{tabular}{lccccc}
\hline \multicolumn{1}{c}{ Tingkat } & hi $(\mathrm{m})$ & Wi $(\mathrm{kg})$ & Wi.hi $(\mathrm{kg} . \mathrm{m})$ & $\mathrm{F}_{\mathrm{ix}, \mathrm{y}}(\mathrm{kg})$ & $\begin{array}{c}\text { Gaya Geser Tingkat } \\
\text { Vx.Vy }(\mathrm{kg})\end{array}$ \\
\hline Atap & 8 & 174411,00 & 1395288,00 & 66781,74 & 66781,74 \\
\hline Lantai 2 & 4 & 725076,68 & 2900306,72 & 138815,45 & 205597,18 \\
\hline Total & & 899487,68 & 4295594,72 & & \\
\hline
\end{tabular}

Simulasi pembebanan akibat gravity load terhadap struktur yang direncanakan diterapkan berdasarkan kaidah tributary area, dimana semua beban pada pelat lantai ditransfer ke elemen balok maupun kolom berdasarkan daerah pengaruh layanan luasan pembebanan disekitar elemen yang ditinjau.

\subsection{Permodelan Struktur}

Analisa struktur terhadap bangunan gedung ini, menggunakan asumsi bahwa sistem struktur yang diterapkan adalah Sistem Rangka Pemikul Momen Biasa (SRPMB) atau beam-column frame. Oleh karena itu balok dan kolom diran- cang sebagai suatu model elemen yang harus mampu memberikan respons atas pembebanan yang berupa gaya normal, lintang, dan momen pada 6 derajat kebebasan (degree of freedom). Kondisi tersebut dilakukan dengan tidak memberi batasan terhadap derajat kebebasan $\left(U_{X}, U_{Y}, U_{Z}, R_{X}, R_{Y}, R_{Z} \neq 0\right.$ ) pada masingmasing nodal elemen balok. Namun demikian khusus untuk elemen kolom, nodal pada kaki kolom di restrain untuk membatasi perpindahannya pada arah sumbu global XYZ $\left(U_{X}, U_{Y}, U_{Z}=0\right)$ sedang rotasi pada titik tersebut tidak dibatasi $\left(R_{X}, R_{Y}, R_{Z} \neq 0\right)$. Hal ini untuk merepresentasikan perletakan sendi. 
Model pembebanan gravity load pada elemen balok dimodelkan sebagai uniform load yang diterima oleh elemen shell sebagai model pelat. Simulasi pembebanan akibat gempa ditinjau secara statik ekivalen, dimana gaya gempa pada masing-masing tingkat bekerja pada pusat kekakuan struktur ditingkat yang ditinjau.

Penyelesaian persamaan-persamaan statika pada model struktur dilakukan menggunakan metode elemen hingga (finite element method) yang terdapat pada program bantu analisa struktur ETABS V 9.07. Permodelan struktur dari gedung tersebut dapat dilihat pada gambar 4.

Hasil analisa struktur (output) yang diharapkan dari proses analisa struktur diatas adalah berupa gaya-gaya dalam (gaya aksial, gaya lintang, dan momen), displacement titik nodal, dan reaksi tumpuan dari column base. Respon struktur akibat beban lateral (story drift) dapat dilihat pada gambar 5 .

\subsection{Kontrol Kekuatan}

\subsubsection{Kontrol kekuatan pelat}

Kekuatan pelat lantai existing dianalisa berdasarkan momen lentur pada model pelat yang dalam hal ini dimodelkan sebagai cangkang (shell). Reaksi yang ditimbulkan akibat kombinasi beban mati dan hidup pada pelat lantai dapat dilihat pada tabel 6 .

Momen resistance $\left(\mathrm{Mn}_{\text {resistance}}\right)$ pada struktur pelat eksisting diasumsikan bahwa luas penampang tulangan pelat memiliki rasio tulangan minimum. Besaran momen tersebut akan dikomparasikan dengan Mn hasil analisa struktur.

Tabel 6. Reaksi Akibat Kombinasi Beban Mati dan Hidup Pada Pelat Lantai

\begin{tabular}{|c|c|c|c|c|c|c|c|c|c|c|c|c|}
\hline Story & $\begin{array}{c}\text { Area } \\
\text { Obj }\end{array}$ & $\begin{array}{l}\text { Area } \\
\text { Type }\end{array}$ & $\begin{array}{c}\text { Output } \\
\text { Case }\end{array}$ & $\mathrm{F}_{\mathrm{MAX}}$ & $\mathrm{F}_{\mathrm{MIN}}$ & $\mathrm{M}_{11}$ & $\mathrm{M}_{22}$ & $\mathrm{M}_{\mathrm{MAX}}$ & $\mathrm{M}_{\mathrm{MIN}}$ & $V_{13}$ & $\mathrm{~V}_{23}$ & $\mathrm{~V}_{\text {MAX }}$ \\
\hline & \multirow{4}{*}{ F120 } & \multirow{4}{*}{ Floor } & \multirow{4}{*}{ LC2 } & & \multirow{4}{*}{0} & 63,94 & 13,45 & 63,94 & 13,45 & $-631,21$ & $-0,86$ & 631,21 \\
\hline & & & & & & $-515,50$ & $-124,77$ & $-124,77$ & $-515,50$ & $-631,21$ & 7,20 & 631,25 \\
\hline & & & & & & $-509,58$ & $-95,97$ & $-95,97$ & $-509,58$ & $-609,45$ & 7,20 & 609,49 \\
\hline & & & & & & 49,90 & 10,01 & 49,90 & 10,01 & $-609,45$ & $-0,86$ & 609,45 \\
\hline
\end{tabular}
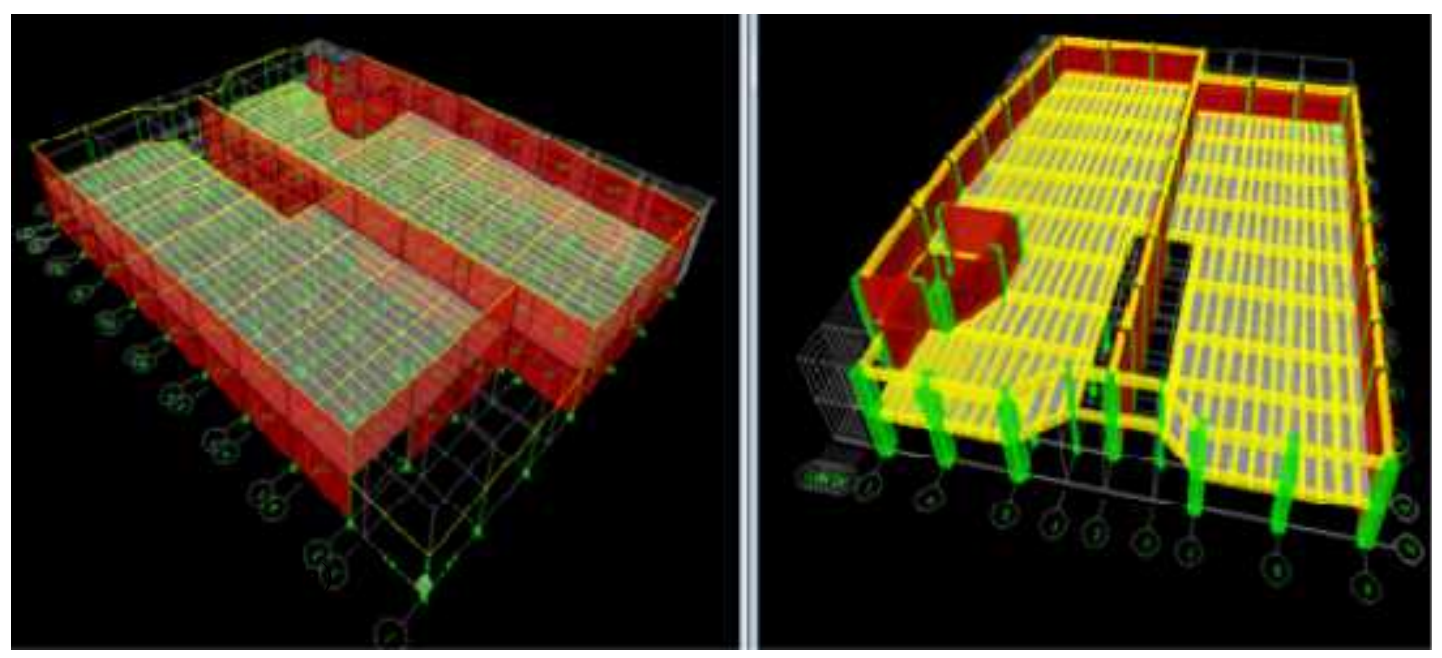

Gambar 4. (a) dan (b) Permodelan struktur gedung jl. Rajawali 3-5, Surabaya 


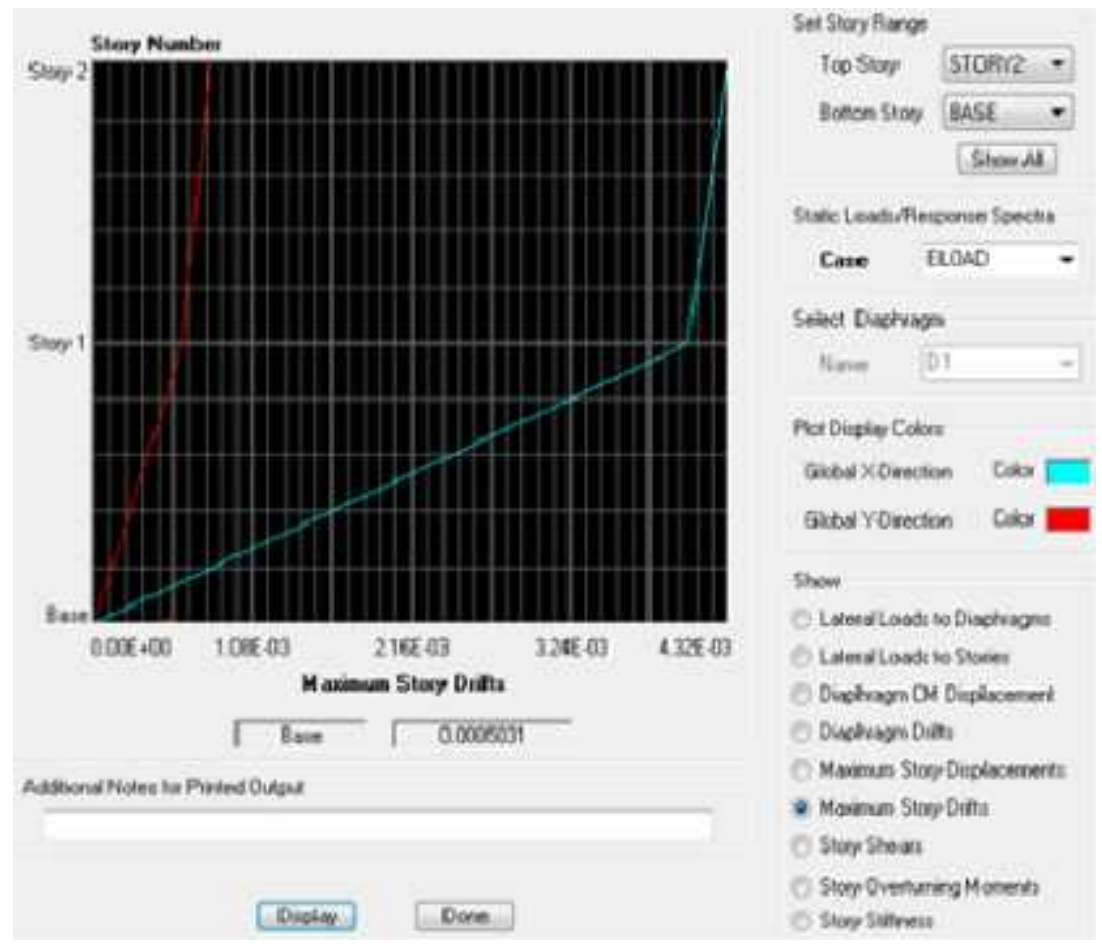

Gambar 5. Diagram story drift model struktur gedung jl. Rajawali 3-5, Surabaya

Perhitungan Momen Kapasitas Plat

Data:

$\mathrm{b}=1000 \mathrm{~mm}$

$\mathrm{h}=120 \mathrm{~mm}$

$\mathrm{d}^{\prime}=25 \mathrm{~mm}$

$\mathrm{d}=95 \mathrm{~mm}$

$\mathrm{fc}=17,4 \mathrm{MPa}$

fy $=220 \mathrm{Mpa}$

Tulangan:

$$
\begin{aligned}
\text { As } & =604,55 \mathrm{~mm}^{2} \\
\mathrm{a} & =13,04 \mathrm{~mm} \\
\mathrm{Mn} & =\text { As.fy }(\mathrm{d}-\mathrm{a} / 2) \\
& =9414313,73 \quad \mathrm{~N} \cdot \mathrm{mm} \\
& =941,43 \mathrm{~kg} \cdot \mathrm{m} \\
\mathrm{Mu} & =0,8 \times 941,43=753,14 \mathrm{~kg} \cdot \mathrm{m}>\mathrm{Mu} \\
\text { perlu } & =515,5 \mathrm{~kg} \cdot \mathrm{M}(\mathrm{ok})
\end{aligned}
$$

Oleh karena itu pelat eksisting masih mampu menerima kombinasi beban mati dan beban hidup akibat perubahan/alih fungsi bangunan.

\subsubsection{Kontrol kekuatan balok}

Elemen-elemen struktur balok beton bertulang yang terdapat pada konstruksi gedung, terdiri dari balok anak dan balok induk yang terangkai dalam konfigurasi grid system. Dengan demikian pola tersebut membentuk model pelat lantai merupakan one way slab. Hasil analisa struktur terhadap kedua jenis elemen balok pada elemen terpilih (selected output) tersebut dapat diresume sebagaimana tabel 7 .

Perhitungan Momen Kapasitas Balok

Data :

$$
\begin{aligned}
& \mathrm{b}=200 \mathrm{~mm} \\
& \mathrm{~h}=300 \mathrm{~mm} \\
& \mathrm{~d}^{\prime}=25 \mathrm{~mm} \\
& \mathrm{~d}=275 \mathrm{~mm} \\
& \mathrm{fc}=17,4 \mathrm{MPa} \\
& \text { fy }=220 \mathrm{Mpa}
\end{aligned}
$$

Tulangan:

As $=350,00 \mathrm{~mm}^{2}$ 
Tabel 7.Reaksi Akibat Kombinasi Beban Mati dan Hidup pada Balok Anak 200 x 300 mm

\begin{tabular}{|c|c|c|c|c|c|c|c|c|c|}
\hline Story & Baem & Load & Loc & $\mathrm{P}$ & $\mathrm{V}_{2}$ & $\mathrm{~V}_{3}$ & $\mathrm{~T}$ & $\mathrm{M}_{2}$ & $\mathrm{M}_{3}$ \\
\hline \multirow{9}{*}{ Story 1} & \multirow{9}{*}{ B333 } & \multirow{9}{*}{ LC2 } & 0,00 & \multirow{9}{*}{$-42,06$} & $-424,00$ & \multirow{9}{*}{$-23,31$} & \multirow{9}{*}{$-2,87$} & $-46,56$ & $-332,91$ \\
\hline & & & 0,50 & & $-337,52$ & & & $-34,91$ & $-142,53$ \\
\hline & & & 1,00 & & $-251,03$ & & & $-23,26$ & 4,61 \\
\hline & & & 1,50 & & $-164,54$ & & & $-11,61$ & 108,50 \\
\hline & & & 2,00 & & $-78,05$ & & & 0,05 & 169,15 \\
\hline & & & 2,50 & & 8,44 & & & 11,70 & 186,56 \\
\hline & & & 3,00 & & 94,93 & & & 23,35 & 160,71 \\
\hline & & & 3,50 & & 181,41 & & & 35,01 & 91,63 \\
\hline & & & 4,00 & & 267,90 & & & 46,66 & $-20,70$ \\
\hline
\end{tabular}

$\mathrm{a} \quad=37,75$

$\mathrm{Mn}=\operatorname{As} . \mathrm{fy}(\mathrm{d}-\mathrm{a} / 2)$

$=15777450,98 \mathrm{Nmm}$

$=1577,75 \mathrm{kgm}$

$\mathrm{Mu}=0.8$ x 1577,75 = 1262,20 kg.m >

$\mathrm{Mu}_{\text {perlu }}=332,91 \mathrm{~kg} \cdot \mathrm{m}(\mathrm{ok})$

Hasil analisa struktur terhadap elemen balok induk 250 x 500 pada elemen terpilih (selected output) dapat diresume sebagaimana tabel 8.

Perhitungan Momen Kapasitas Balok Induk

Data :

$\mathrm{b}=250 \quad \mathrm{~mm}$

$\mathrm{h}=500 \mathrm{~mm}$

$\mathrm{d}^{\prime}=25 \quad \mathrm{~mm}$

$\mathrm{d}=475 \quad \mathrm{~mm}$

$\mathrm{fc}=12 \quad \mathrm{MPa}$

fy $=220 \quad \mathrm{MPa}$

Tulangan

$$
\begin{aligned}
\text { As } & =755,68 \mathrm{~mm}^{2} \\
\mathrm{a} & =65,20 \\
\mathrm{Mn} & =\text { As.fy }(\mathrm{d}-\mathrm{a} / 2) \\
& =58839460,78 \quad \mathrm{Nmm} \\
& =5883,95 \mathrm{kgm}
\end{aligned}
$$

$\mathrm{Mu}=0,8 \times 5883,95=4707,16 \mathrm{~kg} \cdot \mathrm{m}>$ $\mathrm{Mu}$ perlu $=2819,04 \mathrm{~kg} \cdot \mathrm{m}(\mathrm{ok})$

\subsubsection{Kontrol Kekuatan Kolom}

Evaluasi untuk elemen kolom $\varnothing 400$ $\mathrm{mm}$ yang terdapat pada konstruksi gedung terdiri dari kolom bulat $\varnothing 400$ $\mathrm{mm}$ dan kolom segiempat 800x600 mm. Berdasarkan data perhitungan penulangan lentur pada gambar 6 dan 7, menunjukkan bahwa kebutuhan prosentase tulangan adalah sebesar $1 \%$ (minimum reinforcement), hal ini menunjukkan bahwa penampang kolom tersebut masih mampu memikul beban akibat alih fungsi bangunan.

\subsubsection{Pondasi Bangunan}

Hasil reaksi tumpuan pada model frame struktur diatas menunjukkan bahwa gaya aksial maksimum yang terjadi adalah

\begin{tabular}{|c|c|c|c|c|c|c|c|c|c|}
\hline Story & Baem & Load & Loc & $\mathrm{P}$ & $\mathrm{V}_{2}$ & $\mathrm{~V}_{3}$ & $\mathrm{~T}$ & $\mathrm{M}_{2}$ & $\mathrm{M}_{3}$ \\
\hline \multirow{3}{*}{ Story1 } & \multirow{3}{*}{ B235 } & \multirow{3}{*}{ LC2 } & 0,00 & \multirow{3}{*}{$-1014,83$} & 296,90 & \multirow{3}{*}{$-24,45$} & \multirow{3}{*}{12,97} & $-7,08$ & 2819,04 \\
\hline & & & 0,40 & & 441,05 & & & 2,70 & 2671,45 \\
\hline & & & 0,80 & & 585,20 & & & 12,48 & 2466,20 \\
\hline
\end{tabular}
84,024.6 kg akibat kombinasi beban mati, beban hidup, dan beban gempa statik ekivalen. Bilamana diperkirakan

Tabel 8. Reaksi Akibat Kombinasi Beban Mati dan Hidup pada Balok Induk 250 x 500mm 


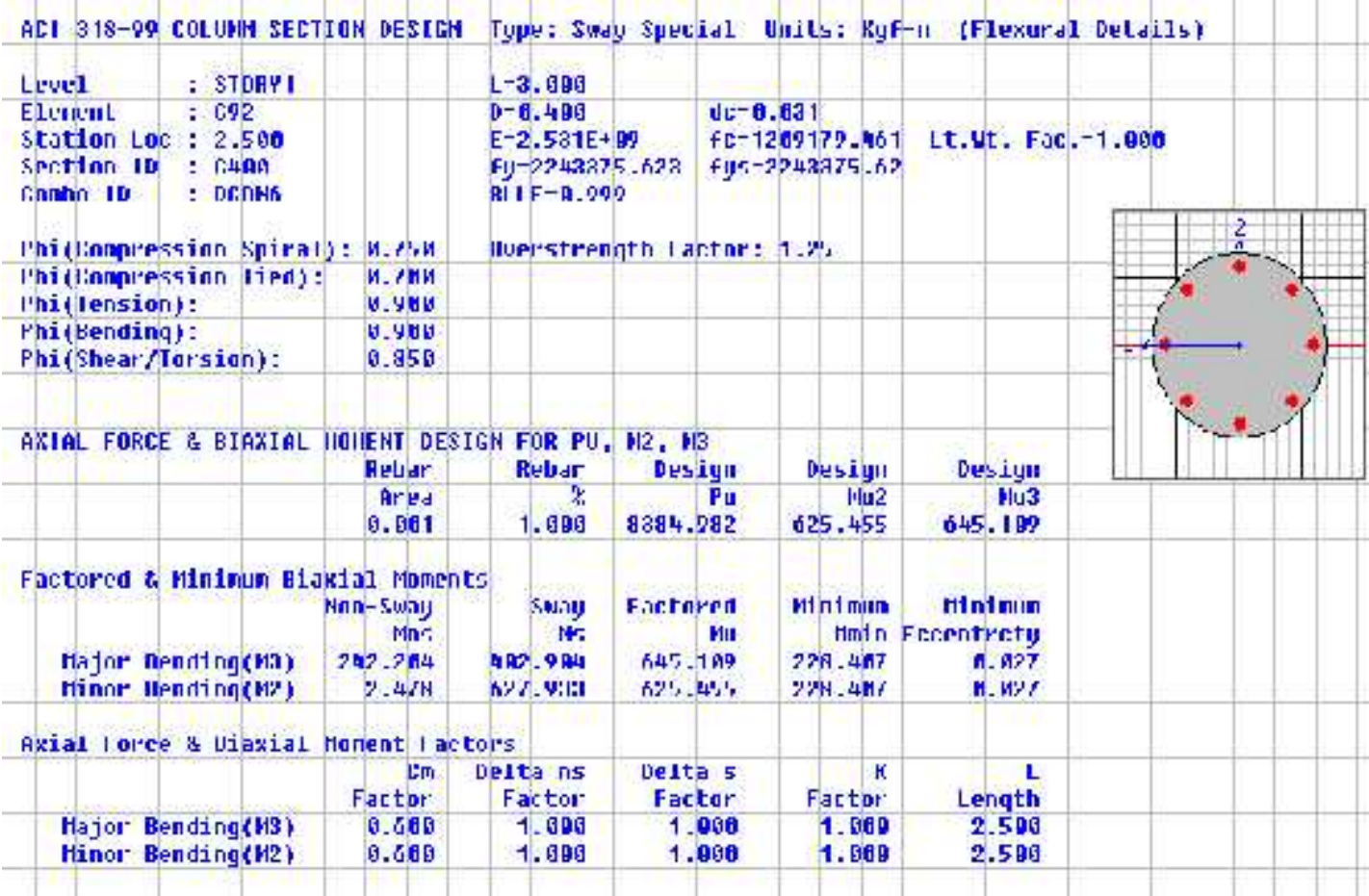

Gambar 6. Hasil perhitungan kontrol kekuatan kolom bulat diameter $400 \mathrm{~mm}$

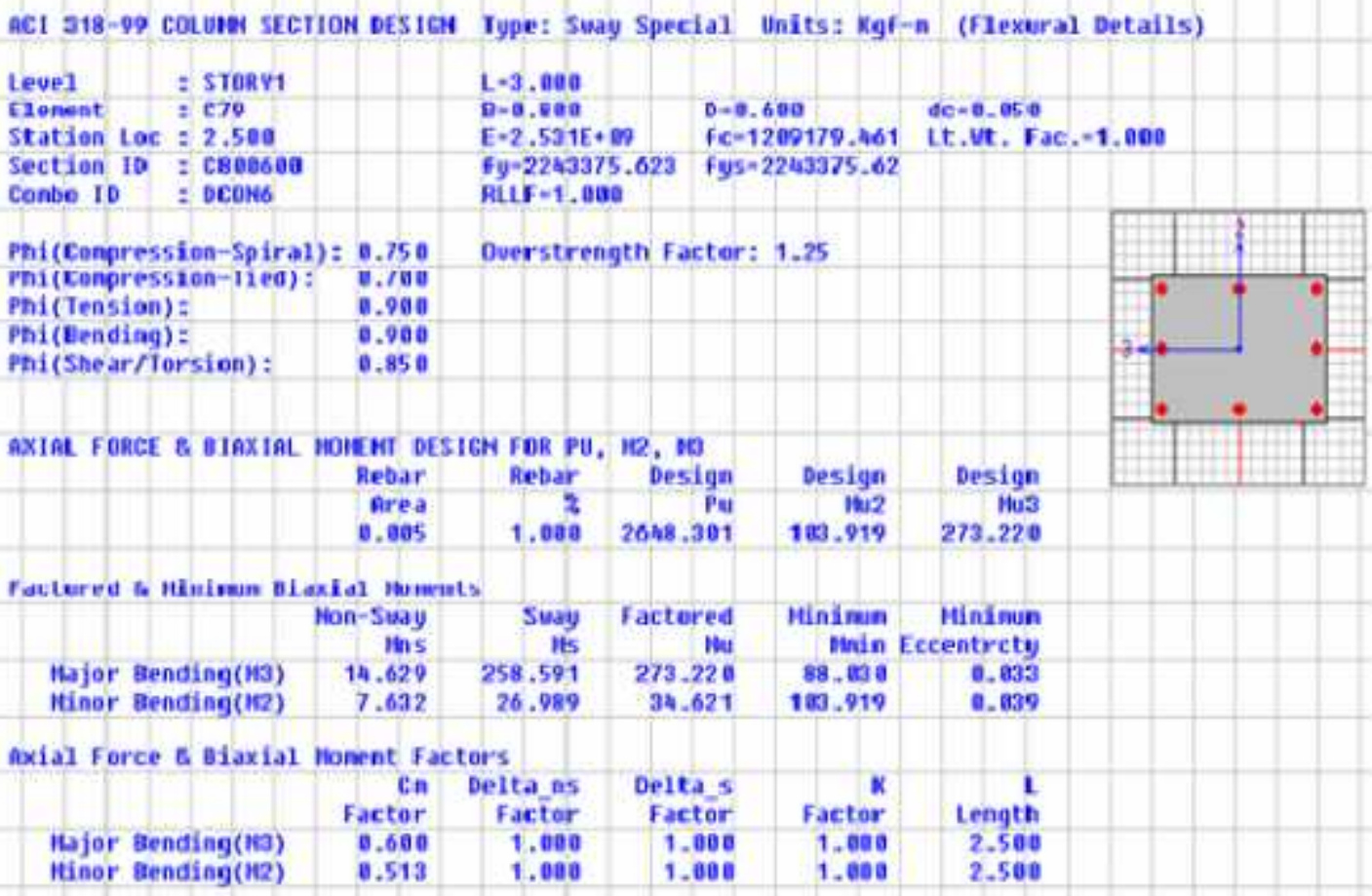

Gambar 7. Hasil perhitungan kontrol kekuatan kolom Kolom Segiempat 800 x 600 mm

bahwa model struktur pondasi bangunan adalah pondasi full plate sesuai trybutary area beban yang dipikul kolom maka luasan pelat pondasi $4,00 \mathrm{x}$ 
4,00 $\mathrm{m}$ sehingga tegangan tanah yang terjadi adalah $0.525 \mathrm{~kg} / \mathrm{cm}^{2}$.

Besaran gaya reaksi tersebut apabila dikomparasikan terhadap daya dukung ijin tanah hasil tes bor memiliki safety factor (SF) berkisar 1,5 dan kedalaman pondasi diperkirakan pada tanah kedalam -2,00 m. Dengan demikian bangunan tersebut masih memiliki faktor keamanan yang cukup, disamping kondisi tanah yang sudah terkonsolidasi selama beberapa puluh tahun silam.

\section{Kesimpulan}

Dari evaluasi secara visual dan analisa perhitungan yang telah dilakukan, maka sehubungan dengan rencana untuk memfungsikan kembali gedung ini sebagai gedung perkantoran dapat diambil kesimpulan sebagai berikut:

Gedung yang terletak di jalan Rajawali no. 3-5 Surabaya ini, ditinjau dari kondisi strukturnya masih layak digunakan kembali dengan fungsi sebagai gedung perkantoran dengan perbaikan dan perkuatan pada pelat lantai, balok anak, balok induk, kolom dan pelat tangga.

Pada evaluasi perbaikan struktur gedung ini, tidak dilakukan evaluasi terhadap elemen-elemen arsitektural.

\section{Daftar Pustaka}

ACI214R-02, Evaluation of Strength Test Results of Concrete, Amerika. SNI 03-1726-2002, Tata Cara Perencanaan Ketahanan Gempa Untuk Bangunan Gedung, Jakarta: Departemen Pekerjaan Umum.
SNI 03-2847-2002, Tata Cara Perhitungan Struktur Beton untuk Bangunan Gedung, Jakarta: Departemen Pekerjaan Umum.

BS 1881-125:1986, Testing concrete Methods for mixing and sampling fresh concrete in the laboratory, British.

PT. Kemitraan, 2011, Evaluasi dan Perbaikan Struktur Gedung PT. Mandiri, Surabaya: PT. Kemitraan. 
Halaman ini sengaja dikosongkan 